Investigaciones Fenomenológicas, n. 9, 2012, 145-156.

e-ISSN: $1885-1088$

\title{
HUSSERL ON ETHICAL RENEWAL AND PHILOSOPHICAL \\ RATIONALITY: INTERCULTURAL REFLECTION
}

\author{
Chung-Chi Yu \\ National Sun Yat-sen University (Kaohsiung), Taiwan \\ ccyuster@gmail.com
}

\begin{abstract}
In the Kaizo articles, written between 1922 and 1924, Husserl drew on the intercultural relationship between Europe and non-Europe. The viewpoints he held in these articles do not deviate much from that in the Vienna lecture 1935, which is later included in Crisis. It is in the latter that Husserl delineates systematically what he thinks of the idea of Europe and what makes Europe different from the other parts of the world. Notably, these viewpoints were already disclosed in the Kaizo articles, though in very different contexts. As is well known, the background of Crisis is the concern about the modern science which deviates more and more from the concrete lifeworld, whereas the Kaizo articles focus mainly on the ethical problems. Nevertheless both of them touch on the cultural as well as intercultural problematic, that Husserl deals with more and more intensively in his late philosophy. My essay will discuss the following questions: On what grounds does Husserl think that the philosophical rationality of Europe deserves being recommended to other cultures? How does he come to this conclusion in his discourse on ethics? In order to come to terms with these questions I will unfold my essay in three steps: first, I will sketch how Husserl understands ethics; secondly, explain the connection between ethics and philosophical rationality, and thirdly how these ethical thoughts have intercultural relevance.
\end{abstract}

Keywords: Husserl, Europe, ethics, philosophical rationality, intercultural.

\begin{abstract}
Resumen: En los artículos de Kaizo, escritos entre 1922 y 1924, Husserl se centró en la relación intercultural entre Europa y no-Europa. Los puntos de vista que él expresó en esos artículos no se desvían mucho del de la conferencia de Viena de 1935, que más tarde se incluiría en La crisis. Es en el último en el que Husserl esboza sistemáticamente lo que piensa de Europa y lo que la hace diferente de otras partes del mundo. Estos puntos de vista ya aparecían especialmente en los artículos de Kaizo, aunque en contextos muy diferentes. Como es bien sabido, el fondo de La crisis es la preocupación acerca de la ciencia moderna que se desvía cada vez más del mundo de la vida concreto, mientras que los artículos de Kaizo se centran principalmente en los problemas éticos. Sin embargo, ambos aluden a la problemática tanto cultural como intercultural a la que Husserl dedica cada vez más atención en su filosofía posterior. Mi artículo tratará los siguientes temas: ¿En qué se basa Husserl para creer que la racionalidad filosófica de Europa merece ser recomendada a otras culturas? ¿Cómo llega a esta conclusión en el discurso sobre la ética? Para aceptar estas preguntas desarrollaré el artículo en tres pasos: en primer lugar, esbozaré cómo Husserl entiende la ética; en segundo lugar, explicaré la conexión entre la ética y la racionalidad filosófica, y en tercer lugar hablaré de cómo estos pensamientos éticos tiene relevancia intercultural.
\end{abstract}

Palabras clave: Husserl, Europa, ética, racionalidad filosófica, interculturalidad.

\section{INTRODUCTION}

In the Kaizo articles, written between 1922 and 1924, Husserl reflected on the intercultural relationship between Europe and non-Europe. The viewpoints 
he held in these articles do not differ much from those in the Vienna lecture 1935, which is later included in Crisis ${ }^{1}$. It is in the latter that Husserl delineates systematically what he thinks of the idea of Europe and what makes Europe different from the other parts of the world. Notably these viewpoints were already disclosed in the Kaizo articles, though in very different contexts. As is well known, the background of Crisis is the concern about modern science, which deviates more and more from the concrete lifeworld, whereas the Kaizo articles focus mainly on the ethical problems. Nevertheless both of them touch on the cultural as well as intercultural problematic that Husserl deals with more and more intensively in his late philosophy.

Husserl deals with the Europe/non-Europe issue in two distinct ways, the one in the context of modern science and the other in an ethical context. The second way of Husserl's dealing with Europe/non-Europe issue will be the focal point of my present essay. The questions to be discussed include: On what grounds does Husserl think that the philosophical rationality of Europe deserves being recommended to other cultures? How he comes to this conclusion in his discourse on ethics? In order to come to terms with these questions I will develop my paper in three steps: I will first sketch how Husserl understands ethics; secondly, explain the connection between ethics and philosophical rationality; and thirdly, show how these ethical thoughts have intercultural relevance.

\section{HUSSERL ON ETHICS AND RENEWAL}

The way Husserl deals with the problem of renewal, which the Japanese term Kaizo designates, is focused on ethics, but nevertheless refers to the dimension of culture. In brief, one can say that on the individual level, renewal is related to the elevation of humanity, which Husserl considers to be the core problem of ethics, whereas on the collective level, it is the elevation of the culture that one is concerned with. The elevation needs to be done through the introduction of philosophy, which Husserl renders as rigorous science. It is in this way that Husserl responds to the cultural crisis that resulted from the First

\footnotetext{
${ }^{1}$ Ernst W. Orth, "Interkulturalität und Inter-Intentionalität: zur Husserls Ethos der Erneuerung in seinen japanischen Kaizo Artikeln", Zeitschrift für Philosophische Forschung 47 (1993), p. 334.
} 
World War. It is philosophical rationality that Husserl calls on in order to deal with such a crisis. Rationality, which is the precious heritage from ancient Greece, provides the European with a helpful way to go through that crisis of culture, but also deserves being recommended to other cultures such as Japan. The invitation by the journal of Kaizo to write these articles can be regarded as a motivation for Husserl to think over the value problem systematically, but actually the ethical and practical as well as cultural problem on individual and the collective level had become Husserl's concerns during the years immediately after the First World War².

Husserl depicts the renewal as ethical problem. Why is renewal so closely related to ethics? As long as renewal denotes transformation, what is the direction of such a transformation? Why is it necessary to make such a transformation? Wherein lies the value of such a transformation? What role does ethics play in such a context? These are questions that need to be discerned first.

The people living in the natural attitude do not reflect much on their own actions and way of living. They lead their lives no other than for the sake of pragmatic requirements. Their living follows certain determinations and rhythms, not only laws of nature, but also socio-cultural regulations. What do they have to do or not to do depend mainly on their context of rules. Whether their mode of living follows the demand of reason is not their main concern. Ethics deals with the human behavior, particularly that which concerns morality. If it focuses on what norms people actually follow, regardless whether these norms are justifiable or not, whether these norms are based on necessity, then such ethics would be named "empirical-human ethics" (empirisch-humane Ethik). Ethics of this sort is concerned with how people live according to certain norms, how they accept the validity of these norms ${ }^{3}$. Such an ethics is not devoid of value, yet it is not what Husserl has in mind when he calls for a study of the universal, apriori aspects of ethical norms. What one needs to pay more attention to is what he calls the science of practical reason (Wissenschaft von der praktischen Vemunft) ${ }^{4}$.

\footnotetext{
${ }^{2}$ H. Reiner Sepp/ Thomas Nenon, "Einleitung des Herausgebers", in Aufsätze und Vorträge 19221937 (Hua XXVII), Hans Reiner Sepp/Thomas Nenon (Hrsg.), p. xi.

${ }^{3}$ Hua XXVII, p. 20. La sigla corresponde, con indicación de tomo y página, a Edmund Husserl, Gesammelte Werke-Husserliana, Vol. XXVII, Dordrecht, Springer, 1988.

${ }^{4}$ Ibidem, p. 21.
} 
Husserl holds that leading a life based on the best knowledge and conscience is what one should absolutely $\mathrm{do}^{5}$. But how can one achieve such a mode of living? The crucial point is reflection and rational thinking. Reflection signifies that one does not just carry on his life naively; instead he evaluates what he does, whether the goal is meaningfully achieved and how he feels during the process of all his efforts. It is an ability to review his own mode of life and all kinds of behavior. In Husserl's view, reason can best disclose itself not otherwise than in the activity of reflection. The more one can reflect on his whole life, the more he can actualize the rational form of life ${ }^{6}$.

Reflection and the ensuing rational thinking make a person keenly aware of what he should do and what he should not. How can one act according to the best knowledge and conscience? This question is understood by Husserl as no other than the question: What categorical imperative one imposes upon himself. The content of the categorical imperative is "to lead a life based on practical reason"7. A life is completely justifiable as long as one's life is based on practical reason. It is also the way that one becomes a genuine person (wahrer Mensch), that is, a person who follows the demands of absolute reason. For Husserl, only the one who takes care of his life according to practical reason can be seen to be "ethical person" (ethischer Mensch), which means nothing other than a genuine person.

To sum up, the ethical question is relevant to the question of how to become a person who represents true humanity. This is also what Kaizo, renewal, means to express verbally. For a person to transform from a lower status to the higher is a big issue. The transformation is disclosed by way of ethical dimension, through the way that one is leading his life in accordance with practical reason. Conversely, one may also say that the ethical life is the life guided by the idea of renewal. Both ethics and renewal are very closely related in Husserl's view.

Furthermore, compared to all the other vocational modes of life, the ethical form of life is viewed by Husserl as the most valuable. It is even the only mode of life that has absolute value. Taking the artist as example, Husserl points out that the artist cannot be regarded as representing the true humanity in the

\footnotetext{
${ }^{5}$ Ibidem, p. 33.

${ }^{6}$ Ibidem, p. 35.

${ }^{7}$ Ibidem, p. 36.
} 
highest degree. Only by adding the ethical dimension can the artist be seen to be so, because no other mode of life can possess the highest, that is, the universal and absolute evaluation than the ethical life ${ }^{8}$.

As a result, the ethical life is a life beginning with the willingness to undertake renewal, and such willingness has to be carried out over and over. Only out of freedom, that is, willingness of one's own, can one grasp true humanity and subsequently also happiness. This is also called by Husserl Urstiftung.

According to Husserl, all the activities of an individual constitute the cultural field of this person. Any individual is both the subject and object of culture. Being a cultural object means that the person is modified by the culture, no matter whether he is unconsciously modified or consciously co-constituted with practical reason, it is apparent that he cannot absolutely avoid being modified. But this is not the only relation between culture and the person. The individual can be seen to become the subject of culture. Through the original Urstiftung, he can transform himself completely into a new person. In this sense, Husserl calls the person with the true humanity "causa sui", that is, self-caused. Only thus can he be seen to make the true renewal. In this context Husserl expresses emphatically that a forced renewal would be deprived of all values. Only the renewal from freedom, out of one's own willingness, can be seen to reach the true humanity and is also the only way to get happiness ${ }^{9}$.

After dealing with the ethics on the individual level, Husserl moves on to handle ethics on the collective level. As mentioned above, people do not only live in the natural environment, but also in social milieu. Under such circumstances, one has the tendency to pursue not only the good for himself, but also the good of others. He wishes to see that other persons may also lead their lives in accordance with morality. Beyond that, he also desires his own community to be ethical. In Husserl's own words, the true person likes to see his community to be true community, he wishes that he is a member of such a community ${ }^{10}$. In sum, the individual good is not at all the end of his ethics, only the collective good can truly meet this requirement.

Conversely, as long as all people have to live in historically cultural environment, the impact of the latter on the former is indispensible. The collective

\footnotetext{
${ }^{8}$ Ibidem, p. 29.

${ }^{9}$ Ibidem, p. 43.

${ }^{10}$ Ibidem, p. 46.
} 
ethics will influence the individual ethics unavoidably. Accordingly, the enhancement of the collective ethics in terms of evaluation will help enhance the individual ethics. There is interplay between the individuality and collectivity in respect of ethics. This is the reason why Husserl deals with the collective ethics as the next step to the individual ethics. On the collective level of ethics, the cultural problem is involved. The enhancement of collective ethics becomes no otherwise than the enhancement of culture. Yet, how to enhance culture? Wherein lies the crucial point? In order to deal with these questions, Husserl moves on to explore the ethical science (ethische Wissenschaft) as well as science in general.

\section{ETHICS AND PHILOSOPHICAL RATIONALITY}

First of all, Husserl points out that the discourse above already has scientific implications. All the ethical problems fall under scientific research. In this context, Husserl does not clearly distinguish between science (Wissenschaft), ethical science (ethische Wissenschaft), and scientific ethics (wissenschaftliche Ethik). I will conceptualize his science as the rigorous science (strenge Wissenschaft), which is what Husserl understands philosophy to be. Therefore when we talk about the ethical science or scientific ethics, we may conceive of it directly as philosophical ethics.

The philosophical ethics aims not only at the understanding of the idea of person, the construction of notions such as environing world as well as the classification of diverse ethical manifestations, but also the normalization of life and the working out of the idea of norms. In other words, the enterprise of philosophical ethics involves two distinct dimensions: the theoretical and the practi$\mathrm{cal}^{11}$.

The value of theory is unquestionable. Husserl has confirmed this point over and over; even in ethics the value of theory is not diminished. He thinks that even in the ethical interests the valuable life nevertheless relies on developing the theoretical interest ${ }^{12}$. However, as long as praxis is indispensible in ethics,

\footnotetext{
${ }^{11}$ Marcus Brainard, "For a New World: on the practical impulse of Husserlian Theory", Husserl Studies 23 (2007), p. 17f.

12 Hua XXVII, p. 52.
} 
the rigorous science must turn into technical science for the sake of application and for the sake of realizing the true humanity ${ }^{13}$. The lower value needs to develop to the higher level, the passive life needs to become the active one. It is by way of handling these questions that the philosophical ethics has contributed to developing the true humanity.

This is the case not only in the dimension of the individual, but also in the dimension of the collective. It is related to the question of how a community can become a genuinely ethical community, i.e., a community of reason (Vernunftgemeinschaft). Husserl considers the role of philosophers in a society to be crucial in this context. It depends on whether the philosopher has a position of authority in the society, because philosophy is regarded by Husserl to be the medium for the enhancement of a society to the higher form of rationality. Philosophy helps create the absolute value and such creation itself is part of the absolute life.

This is the case not only on the individual level, but also on the collective level. Philosophers incorporate the organ how a society is conscious of itself. If a society allows the possibility for philosophy to unfold itself, if the philosophers are so respected to be able to develop philosophy as a cultural system, than the community is on the move to becoming a genuine community of reason. This is exactly what happened in ancient Greece, where philosophers succeeded in struggle for a social status in the community dominated by traditional atmosphere of religion. For Husserl the authority of religion is completely incomparable to that of philosophy. The authority of philosophy is not born of traditional heritage; rather it is created over and over. Philosophy counts as the field of ideally objective values (ein eigenes Reich idealer objektiver Werte) ${ }^{14}$.

Put differently, by way of creating the ethical community or the community of reason philosophy makes enormous contributions to the community. Besides the individual level the collective level also stays in constant struggle with ethical progress. For the sake of development, such a struggle is absolutely indispensible. What Husserl designates as collectivity includes not only the separate nations or peoples, but also the whole planet. Letting the whole world be united under the one-culture-unit can be said to be the ultimate ideal for Husserl. Un-

\footnotetext{
${ }^{13}$ Ibidem, p. 55.

14 Ibidem, p. 53.
} 
der such circumstances one can understand why Husserl recommends his ethical thinking to a leading country such as Japan.

\section{INTERCULtURAL ReleVANCE in HusserL's Ethical Thoughts}

E. W. Orth mentions that Husserl's ethical thoughts revealed in the Kaizo articles have the undertone of Eurocentrism, which might embarrass the contemporary readers more or less. Moreover, Orth also points out that the ethical thought of Husserl has become a common heritage for both European and nonEuropean such that the contemporary European are no longer privileged to hold the ethical superiority over the non-European ${ }^{15}$. Orth does not justify his claim that Husserl's ethical thoughts are already shared by the non-Europeans, nor does he reflect deeply on the Eurocentric position of Husserl. The embarrassment is taken up very seriously by those who strongly reject Husserl's idea of one world. Anthony J. Steinbock understands Husserl's one world as disguised expansion of the European homeworld and points out that the idea of one world can be conceived in two ways. On the one hand, "the one world is regarded statically as a substratum or a totality of which the home and the alien are just different interpretations or perspectival adumbrations ${ }^{\prime 16}$. On the other hand, he proposes to grasp the one world genetically. In this case "the one world is said to evolve practically through expansion as the one 'homeworld' of a higher order, making the alien familiar. [...] As a result, the one world is often conceived as a total rational synthesis of actual and possible homeworlds of lower order $^{\prime 17}$. The reason why Steinbock rejects the idea of one world in Husserl is that as long as homework and alienworld are co-constitutive, the one world which encompasses all possible alienworlds would automatically abolish the meaning of homeworld. In such a case, it would lead to absurd consequence that no one can be said to live in his homeworld genuinely. Even if it is logically possible, it is not at all desirable. In Steinbock's conception, Husserl's renewal of ethics should not set up the idea of one world as his ultimate goal. Rather, it

\footnotetext{
${ }^{15}$ Ernst W. Orth, op. cit., p. 334.

${ }^{16}$ Anthony J. Steinbock, "The Project of Ethical Renewal and Critique: Edmund Husserl's Early Phenomenology of Culture", Southern Journal of Philosophy, Vol. XXXII (1994), p. 459.

${ }^{17}$ Idem.
} 
is more crucial to stress the responsibility of every homeworld for all alienworlds.

Zachary Davis purports to express a similar critique on Husserl that the idea of the single unified world is unnecessary result of the renewal. With help of the concept of sympathy, which Husserl developed almost at the same time as he sketched the Kaizo articles, Davis believes himself able to reinterpret the meaning of one world in a significant way. The solidarity between different homeworlds instead of totalization from one center is more endorsed by him in regard to what Husserl signifies as one unified world ${ }^{18}$.

Husserl's remarks on intercultural issues result in a dilemma for the nonEuropean phenomenologists. Let us limit the scope to ethics and express the dilemma as such: Should they insist on denying the Eurocentric position, they may tend to reject Husserlian project of ethics as a whole. Should they tend to accept the project of Husserl, they may have to put up with Eurocentrism more or less. Wherein lies the way out of such a dilemma?

Suggestions have been made that Europe should never be conceived just in the empirical sense, that is, a geographical part on the planet. Rather, one should pay more attention to the transcendental sense. Since Husserl himself has made the distinction between Europe in the spiritual sense and the empirical sense ${ }^{19}$, not a few followers have welcomed such a distinction and suggested to understand Europe by transcendental sense. The Eurocentrism is seen be undermined through such a distinction ${ }^{20}$. But in the eyes of a nonEuropean, it is an undeniable fact that the ethical ideals of philosophical ethics together with philosophy and science have their birthplace in ancient Greece. Even though Europe can be interpreted as transcendental, even though many of her ideals have been recognized as universally acceptable, the geographically mundane sense of Europe never disappears.

For example, from the viewpoint of East Asia, Europe remains foreign, it

${ }^{18} \mathrm{Cfr}$. Davis Zachary, "Husserl on the Ethical Renewal of Sympathy and the One World of Solidarity", Southern Journal of Philosophy, Vol. XLIII (2005) 561-581.

${ }^{19}$ Idem; cfr. Hua XXVII, p. 241.

${ }^{20} \mathrm{H}$. Reiner Sepp, "Homogenization without Violence? A Phenomenology of Interculturality following Husserl", in Dermot Moran / Lester Embree (eds.), Phenomenology: Critical Concepts in Philosophy, New York / London, Routledge, 2004, Vol. IV, pp. 292-299; Toru Tani, "Heimat und das Fremde", Husserl-Studies 9 (1992) 199-216; Klaus Held, "Intercultural Understanding and the Role of Europe, in Dermot Moran / Lester Embree (eds.), Phenomenology: Critical Concepts in Philosophy", New York / London, Routledge, 2004, Vol. IV, pp. 267-279. 
denotes being from outside. This is a fact that can never be dismissed. Supposed one may agree with Husserl that as long as one gets raised to the ethical level in the genuine sense, it would become a minor issue to ask who I am or who you are in term of culture. In the face of the absolute value of ethics, it is more crucial for one to recognize the universal value of ethics than to ask himself about his own cultural background. If only everybody can be led to the transcendental paradise of the phenomenological, intersubjective world proposed by Husserl! But can any other slogan reveal more triumph of Eurocentrism than this? Does it not imply that all non-Europeans are destined to follow the guidance of Europeans?

Such Eurocentric arrogance has always met with resistance. One needs not even to point it out from the side of non-European. Where there is the voice of interculturality, there is severe criticism on Eurocentrism. No culture has ever developed its own cultural ideal on its own. Europe has learned much from other areas since ancient times. Ancient Greece is no exception ${ }^{21}$. How can one hold to the Eurocentric position in face of such historical facts? Also cultural identity has been questioned in the eyes of the upholders of interculturality. Not only every culture learns from other cultures, it is even vital for each culture to respond to the culture from outside. A culture without challenge would become enclosed culture, which repeats only what it has achieved ${ }^{22}$. To sum up, no culture is not comprised of interculturality, such a fact holds good also for Europe.

However, the historical experience since last two centuries teaches that more European elements flow to the non-European than in reverse. As a result, interculturality takes place in a very unbalanced way. While the Europeans or the Westerners may be pleased to integrate the exotic elements to their culture, the non-Westerners learn as much as they can from the West mostly for the sake of struggle for survival. Again and again the non-Europeans have to concede to the Europeans their superiority.

Whatever the interpretation of intercultural relationship may be, the nonEuropean have to acknowledge that they live in an unbalanced cultural situation. Cultural mixture makes up the everyday life of almost all non-Europeans.

${ }^{21}$ Elmar Holenstein, Kulturphilosophische Perspektiven, Frankfurt / M. Suhrkamp, 1998, pp. 233 and 236.

${ }^{22}$ Bernhard Waldenfels, "Verschränkung von Heimwelt und Lebenswelt", in R. A. Mall / Dieter Lohmar (Hrsg.), Philosophische Grundlage der Interkulturalität, Amsterdam, Rodopi, 1993, p. 64. 
Relating this situation to the aforementioned dilemma, we may like to know how we should react to such a miserable situation.

My suggestion is that why non-Europeans should not conceive of such a situation as the chance for transformation of their own cultural traditions. No non-European culture has turned to genuine European culture only because they imitate the European culture. They remain who they are no matter how much they are influenced by Europeans. By the way, resuming the transcendental sense of Europe such as we mentioned before, one can say that granted Europe can be understood transcendentally, her individuality of mundane existence never disappears.

Similar to the relationship between transcendental subjectivity and mundane subjectivity (or person, as Husserl also puts it), Europe should never be conceived only in her transcendental aspect. In a word, the empirical, cultural aspect of Europe should be always respected. So should every non-European culture. As a result, no matter how much the non-European cultures have learned from European culture, no matter how they have been influenced by the Europeans, the impact from outside, from Europe, should be considered an opportunity to transform their own traditions. To speak in the framework of Husserl's ethical project, it is the chance to raise their cultures to a newer, higher degree. Through this way they have enriched their own cultures, rather than becoming just duplication of European culture.

In my view, this is exactly what one should see in the relationship between Europe and non-Europe. No matter how the non-European culture has to put up with the unbalanced cultural situation, it is in the challenge from Europe that they get the opportunity to renew their own tradition. Seen in this way, the people in the non-European world no longer have reason to find only remorse in what they have lost in the past, but rather delight at what they have got as well as what they will continue to get in the future.

\section{OtHer BibliographicAl References}

HUSSERL, Edmund, Die Krisis der europäischen Wissenschaften und die Transzendentale Phänomenologie (Hua VI), Den Haag, Martinus Nijhoff, 1976. 
Welton, Donn, "Husserl and the Japanese", in Dermot Moran/Lester Embree (eds.), Phenomenology: Critical Concepts in Philosophy", New York/London, Routledge, 2004, Vol. IV, pp. 313-340.

Wimmer, Franz, Essays on Intercultural Philosophy, Chennai-Madras, Satya Nilayam, 2002. 